\title{
„Zazdrośnik ten bezustannie usiluje szkodzić tym, którzy szukają Boga". Wpływ bytów demonicznych na losy jednostek i społeczności w Historiach Grzegorza z Tours ${ }^{2}$
}

Kilkanaście lat temu ukazała się na polskim rynku kolejna biografia Marcina Lutra. Praca autorstwa Heiko Obermana w polskim przekładzie otrzymała tytuł Marcin Luter. człowiek między Bogiem a diabłem³ . Podtytuł dobrze oddaje obecne w kulturze masowej przeświadczenie o pewnym dualizmie głoszącym, że dzieje świata są nieustanną walką między Bogiem a diabłem ${ }^{4}$. To powstałe w nowożytności przekonanie o (wszech)mocy diabła próbuje się także przenosić na czasy starożytności i średniowiecza. Robert Wiśniewski w pracy Szatan i jego studzy. Rola diabła i demonów w tacińskiej literaturze hagiograficznej IV-V wieku zauważył, że „wizja świata otaczającego ludzi żyjących u schyłku epoki starożytnej jako niesłychanie silnie zdemonizowanego wydaje się bardzo mocno zakorzeniona we współczesnej nauce, dominuje w pracach o cha-

\footnotetext{
1 Ks. mgr Michał Ludewicz, doktorant w Sekcji Historii Kościoła i Patrologii na Wydziale Teologii KUL; e-mail: mludewicz@wp.pl; ORCID: 0000-0002-9473-7745.

2 Projekt finansowany w ramach programu Ministra Nauki i Szkolnictwa Wyższego pod nazwą „Regionalna Inicjatywa Doskonałości” w latach 2019-2022, nr projektu 028/RID/2018/19, kwota finansowania $11742500 \mathrm{zł.}$

3 H.M. Oberman, Marcin Luter. Człowiek między Bogiem a diabłem, Gdańsk 2004.

4 W opinii J.B. Russella chrześcijaństwo jest religią umiarkowanego dualizmu (a moderate dualist religion). Diabeł ma wielką siłę, by przeciwstawiać się dziełu Chrystusa, ale jego moc jest zawsze ograniczona i kontrolowana przez Boga. Zob. J.B. Russell, Satan. The Early Christian Tradition, Ithaca - London 1981, s. 32.
} 
rakterze syntetycznym i często bywa traktowana jako założenie, którego dowodzić nie ma potrzeby"5. Polemizując z tym poglądem, wspomniany autor stwierdził, że wizja późnoantycznego świata przepełnionego demonami wzięła się z selektywnej lektury dziel hagiograficznych, a konkretnie z oczarowania najbarwniejszym spośród nich - Żywotem św. Antoniego pustelnika autorstwa św. Atanazego z Aleksandrii ${ }^{6}$. Analizując wybrane przez siebie żywoty świętych z IV i V wieku pod kątem obecności diabła, Wiśniewski doszedł do wniosku, że demonologia żywotu św. Antoniego jest zupełnie wyjątkowa, jednakże izolowana ${ }^{7}$. Trudno bowiem dopatrywać się powszechnego strachu przed działaniem demonów mimo przekonania o ich realności ${ }^{8}$.

Celem niniejszego tekstu jest ukazanie, jaki obraz bytów demonicznych wyłania się z lektury dzieła jednego z ostatnich Ojców Kościoła

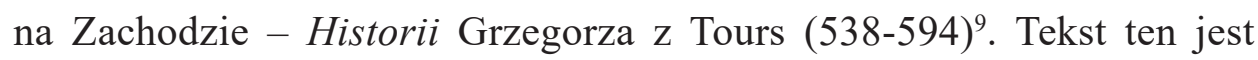
najważniejszym spójnym źródłem do dziejów szóstowiecznej Galii ${ }^{10}$. Bohaterami dzieła Grzegorza są królowie z dynastii Merowingów, możni

5 R. Wiśniewski, Szatan i jego studzy. Rola diabła i demonów w łacińskiej literaturze hagiograficznej IV-V wieku, Kraków 2003, s. 9-10.

6 Por. Wiśniewski, Szatan i jego studzy, s. 11, 261.

7 Por. Wiśniewski, Szatan i jego studzy, s. 267.

8 Przegląd literatury z ostatnich lat oraz wprowadzenie w wieloaspektową tematykę związaną z demonami podaje: N. Vos, Demons and the Devil in Ancient and Medieval Christianity: Introduction, Summary, Reflection, w: Demons and the Devil in ancient and medieval Christianity, red. N. Vos - W. Otten, Leiden - Boston 2011, s. 4-8; Demonologia w nauce ojców Kościoła, Hipolit, O Antychryście, red. H. Pietras, tł. S. Kalinkowski, ŹMT 17, Kraków 2002.

9 Gregorius Turonensis, Historiarum libri X, ed. B. Krusch, Monumenta Germaniae Historica, Scriptores Rerum Merovingicarum, I/1, Hannover 1937-1951, tł. K. Liman T. Richter, Grzegorz z Tours, Historie. Historia Franków, Kraków 2012. Na temat nazw stosowanych dla historycznego dzieła Grzegorza: D.A. Sikorski, Wstęp, w: Grzegorz z Tours, Historie. Historia Franków, Kraków 2012, s. 17-18.

10 Por. I. Wood, Królestwa Merowingów. Władza-społeczeństwo-kultura, Warszawa 2009, s. 41. Zainteresowanie Grzegorza nie ogranicza się tylko do spraw Galii, obejmując również, choć w mniejszym stopniu, Hiszpanię, Italię, Bizancjum, Afrykę i Wschód. Na temat horyzontów geograficznych Grzegorza: D.A. Sikorski, Wstęp, s. 29-31. Na temat samego Grzegorza: M. Heinzelmann, Gregory of Tours: The Elements of a Biography, w: A Companion to Gregory of Tours, red. A.C. Murray, Leiden - Boston 2015, s. 7-34. 
galijscy, biskupi. Sam Grzegorz we wstępie do swojej pracy stwierdził, iż zamierzał pisać o wojnach królów z wrogimi ludami, męczenników z poganami, Kościołów z heretykami ${ }^{11}$. Obok rzeczywistości doczesnej Grzegorz sporo miejsca poświęca bytom duchowym, przywołując Boga Ojca, Chrystusa, świętych (głównie św. Marcina z Tours). W jego dziele pojawiają się także wzmianki dotyczące przeciwników zbawienia - diabła i demonów ${ }^{12}$. W niniejszym tekście zostaną najpierw wskazane nazwy, jakimi posługuje się Grzegorz dla ukazania bytów demonicznych, następnie zostaną przytoczone przejawy działania diabła i demonów opisane przez biskupa Tours. W końcu pokazane zostanie, w jaki sposób Grzegorz przedstawia byty demoniczne w kontekście działania Boga w historii świata.

\section{Charakterystyka bytów demonicznych}

Biskup Tours rozpoczął swoje dzieło od złożenia osobistego wyznania wiary. We fragmencie tym (we wstępie do pierwszej księgi dzieła) znajduje się pierwsza wzmianka na temat bytu demonicznego. Grzegorz był przekonany, że przed końcem świata pojawi się Antychryst (Antechristus) ${ }^{13}$. Kolejna wzmianka dotycząca przeciwnika zbawczych planów Boga pojawia się w relacji na temat pierwszych rodziców, gdzie mowa jest o wężu (anguis), który zwiódł Adama i Ewę do grzechu' ${ }^{14}$.

11 Gregorius Turonensis, Historiarum libri I Praefatio, s. 1, Historie, s. 67.

12 Na temat bohaterów Historii Grzegorza, zob. A.H.B. Breukelaar, Historiography and Episcopal Authority in Sixth-Century Gaul. The Histories of Gregory of Tours interpreted in their historical context, Göttingen 1994, s. 227-267; G. de Nie, Views from a Many-Windowed Tower. Studies of imagination in the works of Gregory of Tours, Amsterdam 1987.

13 Por. Gregorius Turonensis, Historiarum libri I Praefatio, s. 4, Historie, s. 72. Na temat tej postaci: P. Wesołowski, Geneza i istota postaci Antychrysta we wczesnochrześcijańskiej literaturze łacińskiej, „Seminare. Poszukiwania naukowe” 20 (2004) s. 423-439.

14 Por. Gregorius Turonensis, Historiarum libri I 1, s. 6, Historie, s. 73. Przeciwnika zbawienia Grzegorz określa także mianem starodawnego węża (serpens antiquus). Por. 
Przy opisywaniu występków Chusa, wnuka Noego, Grzegorz po raz pierwszy przywołał określenie diabeł (diabolos $)^{15}$. Dla oznaczenia demonicznych bytów biskup Tours używał także terminów nieprzyjaciel

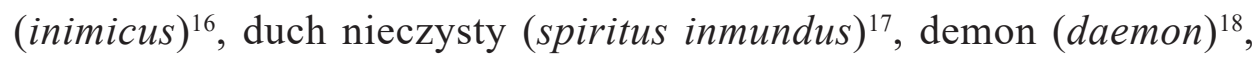
Belial $^{19}$, kłamca od początku (ab initio mendax) ${ }^{20}$, duch fałszu (spiritus erroris) $)^{21}$, zazdrośnik (invidus) ${ }^{22}$, książę ciemności (princeps tenebrarum $)^{23}$, sprawca wszelkiego zła (autor nequitiae) $)^{24}$, tyran (tyrannus) $)^{25}$. Raz tylko, w cytacie z 1 Kor 7,5, pojawia się nazwa Szatan $(\text { Satan })^{26}$.

Gregorius Turonensis, Historiarum libri I 25, s. 20, Historie, s. 83. Symbolikę węża w tradycji chrześcijańskiej wyjaśnia: S. Kobielus, Bestiarium chrześcijańskie. Zwierzęta w symbolice i interpretacji. Starożytność i średniowiecze, Warszawa 2002, s. 325-329.

15 Por. Gregorius Turonensis, Historiarum libri I 5, s. 7, Historie, s. 74. Termin diabolos oznacza 'oszczercę'. Greka klasyczna używała tego pojęcia na określenie bluźniercy, obłudnika, kogoś zniesławiającego. Rdzeniem słowotwórczym jest czasownik $\delta i \alpha \beta a ́ \lambda \lambda \omega$ ('rozdzielić, rozłączyć, czynić zarzuty, zniesławić, zadenuncjować, fałszywie świadczyć, dzielić, stawiać w poprzek'). Por. R. Zając, Przewodnik po niebie, piekle i ich mieszkańcach, Kraków 2014, s. 308.

16 Por. Gregorius Turonensis, Historiarum libri I 30, s. 22, Historie, s. 85.

17 Por. Gregorius Turonensis, Historiarum libri I 45, s. 29, Historie, s. 92.

18 Por. Gregorius Turonensis, Historiarum libri II 3, s. 45, Historie, s. 107. Różne znaczenia terminu ,demon” przytacza: B. Studer, Demon, w: Encyclopedia of Ancient Christianity. Produced by the Institutum Patristicum Augustinianum, t. 1, red. A. di Berardino, Westmontt 2014, s. 688-692.

19 Por. Gregorius Turonensis, Historiarum libri V 6, s. 203, Historie, s. 233. Mianem Beliala według R. Zająca określano w Starym Testamencie ludzi szczególnie niegodziwych. W tekstach z Qumran Belial to synonim przeciwnika ludu bożego i królestwa światłości. Por. Zając, Przewodnik po niebie, piekle i ich mieszkańcach, s. 322.

20 Por. Gregorius Turonensis, Historiarum libri V 14, s. 210, Historie, s. 239.

21 Por. Gregorius Turonensis, Historiarum libri VIII 12, s. 379, Historie, s. 377.

22 Por. Gregorius Turonensis, Historiarum libri VIII 15, s. 382, Historie, s. 380.

23 Por. Gregorius Turonensis, Historiarum libri VIII 34, s. 403, Historie, s. 397. Rolę ciemności w kontekście zła omawia: M.C. Paczkowski, Wczesnochrześcijańska symbolika o charakterze ponerologicznym. Wybrane przykłady, VoxP 59 (2013) s. 43-49.

24 Por. Gregorius Turonensis, Historiarum libri IX 6, s. 417, Historie, s. 409.

25 Por. Gregorius Turonensis, Historiarum libri IX 42, s. 471, Historie, s. 452. O diable, który postępuje jak tyran, wspominał także Atanazy w Żywocie św. Antoniego Pustelnika (por. SCh 400, s. 212-213).

26 Por. Gregorius Turonensis, Historiarum libri I 44, s. 29, Historie, s. 92. Zestawiając terminy „szatan” i „diabeł”, R. Zając zauważa, że śātān to 'przeciwnik oskarżyciel', diabolos natomiast to 'oszczerca, ktoś kto oskarża, ale fałszywie', teologicznie to ktoś, kto 
Wspominając byty demoniczne, Grzegorz używa też liczby mnogiej (daemones $)^{27}$.

Biskup Tours zasadniczo nie opisywał bliżej wyglądu złych duchów. Niekiedy zaznaczał tylko, w jakiej postaci ukazał się demon. Przywołując wydarzenia z początków historii biblijnej w raju, wspomniał o wężu ${ }^{28}$. Więcej szczegółów podał w epizodzie, który przytrafił się biskupowi Eparchiuszowi z Clermont ${ }^{29}$. Biskup ten miał zwyczaj przychodzić na modlitwy w nocy. Gdy pewnego razu wszedł do kościoła, ujrzał świątynię pełną złych duchów wraz z ich przywódcą zasiadającym na tronie. Zły duch przybrał postać pięknej kobiety. Kapłan w ten sposób zwrócił się do zjawy: „O przeklęta nierządnico, nie dość ci, że wszystko kalasz przeróżnymi brudami, to jeszcze i tron poświęcony przez Pana bezcześcisz wstrętnym dotykiem twojego ciała?". Grzegorz dodał, że zjawa zniknęła niczym dym ${ }^{30}$. Stosując przywołaną już nazwę „książę ciemności”, Grzegorz wydaje się również łączyć byt demoniczny z mrokiem. Przytaczając opowieść biskupa Trewiru Magneryka, pasterz Tours zamieścił także wyznanie złych duchów, które złożyły przez usta opętanej kobiety. Wynikało z niego, że demony cierpią męki ogniste spowodowane ich zdaniem modlitwą jednego $\mathrm{z}$ biskupów ${ }^{31}$. Opisując historię nawróconego Żyda, biskup Tours przekazał, że jego były współwyznawca z poduszczenia diabelskiego (diabulo instigante) wylał na neofitę śmier-

wprowadza rozdźwięk między Stwórcą a stworzeniem, oddzielając ludzi od Boga. Por. Zając, Przewodnik po niebie, piekle i ich mieszkańcach, s. 308.

27 Por. Gregorius Turonensis, Historiarum libri II 21, s. 67, Historie, s. 127.

28 Por. Gregorius Turonensis, Historiarum libri I 1, s. 6, Historie, s. 73.

29 Na temat Eparchiusza, zob. R.W. Mathisen, Ecclesiastical Factionalism and Religious Controversy in Fifth-Century Gaul, Washington 1989, s. 199. W komentarzu do polskiego tłumaczenia Historii Grzegorza wkradł się błąd literowy. Śmierć biskupa Namacjusza, poprzednika Eparchiusza na stolicy biskupiej w Clermont, nastąpiła w latach sześćdziesiątych V wieku, a nie w VI wieku, jak omyłkowo podano w przypisie 164 na s. 126.

30 Por. Gregorius Turonensis, Historiarum libri II 21, s. 67, Historie, s. 126-127. Motyw diabła kuszącego pod postacią kobiety obecny jest m.in. w: Athanasius, Vita Antonii 5, 5, SCh 400, s. 145.

31 Por. Gregorius Turonensis, Historiarum libri VIII 12, s. 379, Historie, s. 377. 
dzący olej ${ }^{32}$. Wspominając zaś wydarzenia z Bourges, Grzegorz wspominał człowieka, którego w lesie opadła chmara much i który przez to miał postradać zmysły. To wydarzenie biskup przypisał diabelskiej niegodziwości ${ }^{33}$. Biskup, opisując zamęt powodowany przez diabła, używał także metaforycznego określenia chwast diabelski (zizania diaboli) ${ }^{34}$. Ponadto Grzegorz przywoływał postać Antychrysta ${ }^{35}$, który będzie podawał się za Chrystusa, zakładał więc zapewne jakieś fizyczne podobieństwo do wcielonego Syna Bożego, które miało ludzi wprowadzić w błąd. Używanie takich wyrażeń, jak nierządnica, brud, wstrętny dotyk, dym, ciemności, ogień, olej śmierdzący, muchy, chwast, powodowało, że rzeczywistość diabelska, mimo że pojawia się stosunkowo rzadko w historycznym dziele Grzegorza, pobudzała wyobraźnię, silnie oddziałując na zmysły. Grzegorz nie zajmował się dokładniej światem złych duchów, ale z jego wzmianek na ich temat można dojść do wniosku, że przyjmował w ich świecie istnienie pewnej hierarchii i zróżnicowania. Mówił o ich przywódcy (princeps) ${ }^{36}$. Przywoływał także wyznanie demona, który mówił o innym złym duchu: „,nasz książę, którego wy diabłem nazywacie" ${ }^{37}$. Opisując opętanie kobiety, wspominał o dwóch dręczących ją

32 Por. Gregorius Turonensis, Historiarum libri V 11, s. 205, Historie, s. 235. Motyw łączący diabła z przykrym zapachem odnaleźć można m.in. w zbiorze biografii papieskich Liber Pontificalis. Za pontyfikatu Hadriana II (867-872) potępiono uchwały synodu z Konstantynopola rehabilitujące Focjusza. O potępionym dokumencie synodalnym wypowiedział się jeden z uczestniczących w nim dostojników następująco: „Wierzę, że w tej księdze mieszka diabeł [...]”. Następnie rozkazano spalić dokument. Według Liber Pontificalis ogień trawił go z ohydnym zapachem i smolistym kolorem. Por. Liber Pontificalis XCVII - CXII (ann. 772-891), Synodi et Collectiones Legum 10, tł. Księga Pontyfików 97-112 (772-891), ŹMT 75, Kraków 2015, s. 252*-253*.

33 Por. Gregorius Turonensis, Historiarum libri X 25, s. 517-518, Historie, s. 493. Na temat związku much z diabłem zob. Kobielus, Bestiarium chrześcijańskie, s. 215217. Autor przywołuje pogląd św. Hieronima, że od much nosi imię książę demonów Belzebub, którego imię można zinterpretować jako bóstwo much, męża much albo posiadającego muchy. por. Kobielus, Bestiarium chrześcijańskie, s. 216.

34 Por. Gregorius Turonensis, Historiarum libri VIII 7, s. 67, Historie, s. 376.

35 Por. Gregorius Turonensis, Historiarum libri I Praefatio, s. 4-5, Historie, s. 72.

36 Por. Gregorius Turonensis, Historiarum libri II 21, s. 67, Historie, s. 127.

37 Gregorius Turonensis, Historiarum libri VI 29, s. 296, Historie, s. 308. 
duchach, z których kolejny był jeszcze gorszy od pierwszego ${ }^{38}$. Grzegorz nie podawał wprost wiadomości o miejscu przebywania złych duchów. Wspominał natomiast o piekielnym więzieniu (infernari carcere) jako miejscu, gdzie będą przebywać grzesznicy ${ }^{39}$. Pisał także, że po sądzie, przy końcu świata grzesznicy odejdą wraz z diabłem ${ }^{40}$. Świat diabelski wieloraki w swoich postaciach objawiał swą moc poprzez prowadzenie ludzi do zła. Historyczne dzieło Grzegorza zawiera sporo przykładów zgubnego wpływu, jaki byty demoniczne wywierały na jednostki oraz społeczność.

\section{Przykłady wpływu bytów demonicznych na jednostki i społeczność}

Opisując początki historii świata, Grzegorz przywołał postać Chusa, wnuka Noego. Według biskupa Tours to właśnie Chus z diabelskiego poduszczenia stał się wynalazcą wszelkiego czarodziejstwa (artes magicae) i bałwochwalstwa (idolatria) ${ }^{41}$. Grzegorz twierdził, że kolejnym obeznanym w sztuce czarnoksięskiej był Szymon $\mathrm{Mag}^{42}$. Zdaniem biskupa to właśnie z inspiracji Szymona Neron rozpoczął prześladowanie

38 Por. Gregorius Turonensis, Historiarum libri IX 29, s. 525, Historie, s. 500.

39 Por. Gregorius Turonensis, Historiarum libri X 13, s. 498, Historie, s. 476. W innym miejscu na określenie rzeczywistości podziemnej, dokąd trafią grzesznicy, użył nazwy abyssus ('przepaść, piekło'). Por. Gregorius Turonensis, Historiarum libri VIII 31, s. 397, Historie, s. 393. Na temat terminologii związanej z miejscem przebywania zmarłych po śmierci, zob. M. Szram, Ciało zmartwychwstałe w myśli patrystycznej przełomu II i III wieku, Lublin 2010, s. 414-415, przyp. 49.

40 Por. Gregorius Turonensis, Historiarum libri X 31, s. 536, Historie, s. 510. Na temat poglądów Grzegorza na piekło, zob. K.C. Choda, Facing a Second Death: Narrating and Silencing Hell in the Works of Gregory of Tours, „Graeco-Latina Brunensia” 22/2 (2017) s. 201-216.

41 Por. Gregorius Turonensis, Historiarum libri I 5, s. 7, Historie, s. 74.

42 Na temat Szymona Maga, zob. J. Fossum, Simon Magus, w: Dictionary of Deities and Demons in the Bible, red. K. van der Toorn - B. Becking - P.W. van der Horst, Leiden - Boston - Köln 1999, s. 779-781. 
chrześcijan. Grzegorz wspominał także o pozaludzkim natchnieniu dla działań władcy. Uważał, że cesarzem powodowała zajadła złość, której sprawcą był starodawny wąż $\dot{z}^{43}$. Podobnie diabelska inspiracja miała kierować władcą (Grzegorz nie podał jego imienia, określając go jedynie mianem tyrana ${ }^{44}$, który rozpętał prześladowanie chrześcijan w Galii za czasów biskupa Ireneusza z Lyonu ${ }^{45}$. Powracając do wątku fałszywego kultu, Grzegorz zauważył, że za czasów prześladowań za Decjusza działali, z poduszczenia diabła, Walentyn i Nowacjan, najwięksi w tamtych czasach przywódcy heretyków ${ }^{46}$. Związek pomiędzy herezją a złym duchem Grzegorz podjął ponownie, opisując zbrodnię, jakiej miała się dopuścić córka gockiego króla Teodoryka na swojej matce. Matka była przeciwna małżeństwu córki z człowiekiem niższego stanu, którego kazała zabić. W akcie zemsty córka do kielicha z winem, z którego matka, zwyczajem arian, przyjmowała Komunię świętą, dodała trucizny, tak że matka zaraz po spożyciu umarła. Opisując to wydarzenie, Grzegorz stwierdził: „Jest nie wątpliwe, że zbrodnia ta jest dziełem diabła”. Dodał przy tym: „Cóż na to odpowiedzą nędzni heretycy, że nawet nad ich sakramentem nieprzyjaciel ma moc?" ${ }^{47}$. Po raz kolejny swoją opinię na temat związku między fałszywym kultem a działalnością złego ducha Grzegorz wyraził, opisując historię, jaka przytrafiła się Leonastowi, archidiakonowi z Bourges. Wskutek nachodzącego bielma utracił wzrok.

43 Por. Gregorius Turonensis, Historiarum libri I 25, s. 20, Historie, s. 83.

44 Wprawdzie Grzegorz nie podaje imienia wspomnianego tyrana, ale z innych źródeł wiadomo, że Ireneusz poniósł męczeństwo w 202 roku za panowania Septymiusza Sewera (193-211). Por. J. Danielou - H.I. Marrou, Historia Kościoła, t. 1, Warszawa 1986, s. $122-123$.

45 Por. Gregorius Turonensis, Historiarum libri I 29, s. 21-22, Historie, s. 85.

46 Por. Gregorius Turonensis, Historiarum libri I 30, s. 22, Historie, s. 85. Związek pomiędzy powstawaniem herezji a działalnością szatana omawia: M. Szram, Geneza herezji wczesnochrześcijańskich w ujęciu Filastriusza z Brescii, VoxP 65 (2016) s. 634-635.

47 Por. Gregorius Turonensis, Historiarum libri III 31, s. 126-127, Historie, s. 170. Chociaż historia ta ma charakter legendarny, oddaje jednak poglądy Grzegorza na temat związków pomiędzy diabłem a herezją. Szerzej na temat bohaterek tego epizodu, zob. E.T. Dailey, Queens, Consorts, Concubines. Gregory of Tours and Women of the Merovingian Elite, Leiden - Boston 2015, s. 99-100. 
Odzyskał go cudownie po długich modlitwach zanoszonych do św. Marcina. Kiedy jednak powrócił do domu, kazał wezwać Żyda, aby mu postawił bańki na plecach, aby przez to poprawić sobie wzrok. Wskutek tego zabiegu ponownie popadł w ślepotę. Zdaniem Grzegorza „,byłby on pozostał w zdrowiu, gdyby po bożym cudzie nie wezwał jeszcze Żyda”. W swoim wywodzie Grzegorz cytował słowa św. Pawła „Cóż ma wspólnego światło z ciemnością albo jaka jest wspólnota Chrystusa

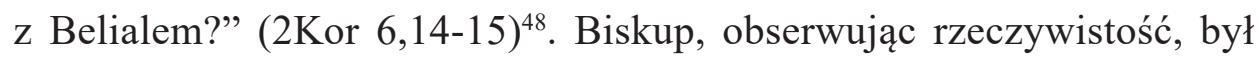
przekonany, że żyje w czasach ostatecznych. Jednym z symptomów nadchodzącego końca było wypełnienie się słów Ewangelii zapowiadającej nadejście fałszywych mesjaszy wprowadzających w błąd wierzących (Mk 13,22). Przykładu dostarczył Grzegorzowi pewien Dezyderiusz, który przybył do Tours i podawał się za kogoś wielkiego. Intruz przechwalał się, że potrafi czynić wiele cudów i ma kontakt z apostołami Piotrem oraz Pawłem. Grzegorz zwracał uwagę na jego znajomość rzeczy tajemnych, której miał udzielić mu diabeł ${ }^{49}$. W ostatniej księdze swojego dzieła opowiedział o człowieku, który przybył do miasta Javols, podając się za samego Chrystusa. Dobrał on sobie towarzyszkę, którą kazał nazywać Marią. Zdaniem Grzegorza był on pod wpływem diabła, który udzielił mu daru wieszczenia. Potrafił on przepowiadać przyszłość i uzdrawiać, a swoim zachowaniem zdołał zwieść wielką rzeszę ludzi. Grzegorz dodawał, że byli wśród nich nie tylko prostaczkowie, ale także kapłani Kościoła. Jeszcze długo po śmierci tego człowieka ludzie nadal uznawali go za Chrystusa i wierzyli, że owa Maria miała udział w jego bóstwie ${ }^{50}$. Obok herezji i fałszywych kultów Grzegorz dopatrywał się działania złych duchów także w uprawianiu wróżbiarstwa. Biskup opowiedział zdarzenie, jak to król Guntchramn posłał swego sługę do kobiety obdarzonej duchem proroczym (spiritus phitonis), aby mu przepowiedziała

\footnotetext{
48 Por. Gregorius Turonensis, Historiarum libri V 6, s. 203, Historie, s. 233.

49 Por. Gregorius Turonensis, Historiarum libri IX 6, s. 417, Historie, s. 408-409.

50 Por. Gregorius Turonensis, Historiarum libri X 25, s. 517-519, Historie, s. 493-494.
} 
przyszłość. Kobieta zdradziła królowi, że ten dostąpi godności biskupa Tours. Grzegorz przekazał, że król na te słowa uniósł się pychą, ,,jak gdyby już siedział na biskupim tronie w Tours". Biskup jednak pouczył władcę, że nie sposób wierzyć temu, co diabeł przyrzeka, gdyż od początku był on kłamcą i w prawdzie nie wytrwał ${ }^{51}$. Inny epizod dotyczył kobiety, która również miała ducha wróżbiarskiego i za pieniądze udzielała rad ludziom, których okradziono, wskazując, gdzie ukryto ich mienie. Gdy o jej działalności dowiedział się biskup Ageryk, próbował wypędzić z niej ducha nieczystego, odmawiając egzorcyzmy i namaszczając jej czoło olejem. Grzegorz podawał, że zabiegi biskupa zakończyły się niepowodzeniem $^{52}$. W dziele pasterza Tours kilkukrotnie pojawia się wątek łączący działanie diabła z kobietą. Po raz pierwszy niewiasta i wąż zostali wspólnie przywołani przy opisie grzechu popełnionego w raju ${ }^{53}$. Kolejny raz Grzegorz powrócił do tego motywu, opisując życie biskupa Clermont Urbikusa, który miał żonę. Oboje oddawali się modlitwie, jałmużnie i dobrym uczynkom. Stan ten jednak został zakłócony. Według Grzegorza zazdrość nieprzyjaciela, „która zawsze jest wrogiem świętości, zwróciła się ku kobiecie, rozpaliła w niej pożądanie męża i uczyniła nową Ewą". Udała się do miejsca spoczynku biskupa i zaczęła dobijać się do drzwi, domagając się wpuszczenia do środka. Jak relacjonuje Grzegorz, biskup w końcu ostygł w swej gorliwości i dopuścił kobietę do siebie. Potem ,poniewczasie przyszedł do siebie” i żałując popełnionego występku, udał się do jednego z klasztorów swojej diecezji dla odbycia pokuty $^{54}$. Grzegorz wspomniał także o żonie biskupa Priskusa z Lyonu. Kobieta ta opętana przez demona z rozpuszczonymi włosami biegała po

51 Por. Gregorius Turonensis, Historiarum libri V 14, s. 210, Historie, s. 238-239.

52 Por. Gregorius Turonensis, Historiarum libri VII 44, s. 364-365, Historie, s. 363. Szerzej epizod ten omawia: R. Wiśniewski, Wieszczacy opętani i ich klienci w późnej starożytności, red. E. Wipszycka - T. Derda, Chrześcijaństwo u schyłku starożytności. Studia Źródłoznawcze 5, Kraków 2004, s. 353.

53 Por. Gregorius Turonensis, Historiarum libri I 1, s. 5-6, Historie, s. 73.

54 Por. Gregorius Turonensis, Historiarum libri I 44, s. 28-29, Historie, s. 91-92. 
całym mieście ${ }^{55}$. Wśród skutków działania złego ducha Grzegorz opisuje samobójstwa, przemoc i rabunek, kłótnie. Biskup Tours kilkukrotnie wspomina o prześladowcach chrześcijan, którzy odebrali sobie życie. Tak postąpili m.in. Piłat ${ }^{56}$, Herod $^{57}$, Neron $^{58}$. W przypadku wandalskiego króla Huneryka Grzegorz ubarwił swoją narrację szczegółami o charakterze legendarnym. Zdaniem biskupa król, który długo karmił się krwią świętych, rozszarpał się własnymi zębami. Według duchownego z Tours król postąpił tak, będąc opętanym przez demona ${ }^{59}$. W dalszej części swojego dzieła Grzegorz opisał samobójczą śmierć Palladiusza, byłego królewskiego namiestnika. Na wieść, że król zamierzał go zabić, dostojnika ogarnęła bojaźń i postanowił sam odebrać sobie życie. Mimo że pilnowali go bliscy, wykorzystał moment ich nieobecności i dwukrotnie przebił się mieczem. Według Grzegorza jasne było, że tylko z pomocą diabelską mógł on dokonać takiego postępku ${ }^{60}$. Widocznym znakiem działania złego ducha były również przemoc i rabunek. Grzegorz opisał napad na klasztor w Latta, gdzie znajdowały się relikwie św. Marcina. Zauważył przy tym, że część złodziei wycofało się i zaniechało przestępstwa, tylko dwudziestu, którzy nie lękali się Boga ani nie szanowali św. Marcina, przystąpili go rabunku. Kronikarz zaznaczył, że działali oni podpuszczeni przez złego ducha. Dodał także, że wszyscy oni ponieśli śmierć, próbując przeprawić się z zagarniętymi łupami przez rzekę ${ }^{61}$. Podobny los spotkał żołdaków, którzy obrabowali skarby zdeponowane w kościele św. Wincentego w Agen. Podczas rabunku wybuchło zamieszanie, w trakcie

55 Por. Gregorius Turonensis, Historiarum libri IV 36, s. 168-169, Historiarum libri, s. 206-207.

56 Por. Gregorius Turonensis, Historiarum libri I 24, s. 19, Historie, s. 83.

57 Por. Gregorius Turonensis, Historiarum libri I 24, s. 19, Historie, s. 83.

58 Por. Gregorius Turonensis, Historiarum libri I 25, s. 20, Historie, s. 84.

59 Por. Gregorius Turonensis, Historiarum libri II 3, s. 45, Historie, s. 107.

60 Por. Gregorius Turonensis, Historiarum libri IV 39, s. 171, Historie, s. 208-209. Na temat Palladiusza zob. The Prosopography of Later Roman Empire A. D. 527-641, t. 3B, red. B.J.R. Martindale, Cambridge 1992, s. 961.

${ }_{61}$ Por. Gregorius Turonensis, Historiarum libri IV 48, s. 185, Historie, s. 218. 
którego rabusie poranili siebie nawzajem. Wielu z nich, opętanych przez demona, złorzeczyło św. Wincentemu ${ }^{62}$. Sporo miejsca Grzegorz poświęcił postaci Eberulfa, kubikulariusza królewskiego ${ }^{63}$. Dostojnik ten oskarżony o zabójstwo schronił się w kościele św. Marcina w Tours. Świątynia ta pozostawała pod zarządem Grzegorza, który musiał mierzyć się z obecnością intruza. Pijany Eberulf przeszkadzał w modlitwach, lżył i przeklinał duchownych. Takie zachowanie Grzegorz przypisał opętaniu przez demona $^{64}$. Był nawet przekonany, że przez usta rabusia grożącego duchownym śmiercią przemawiał sam diabeł ${ }^{65}$. Kolejny raz Grzegorz połączył przemoc i pijaństwo z działaniem złego ducha, opisując postać kapłana Winnoka. Ludzie przynosili mu wino, tak że przyzwyczaił się do tego napoju. Pijany popadał w szał i uzbrojony w nóż, kamień bądź kij biegał za ludźmi. Biskup z Tours był przekonany, że opętał go demon. Rozpoczynając swoją relację o występkach kapłana, Grzegorz wspomniał, że książę ciemności (princeps tenebrarum) zna tysiące sposobów aby szkodzić6 ${ }^{66}$. Wyraźnym znakiem działania złego ducha były dla biskupa Tours kłótnie i nieposłuszeństwo. Opisując wymianę zdań pomiędzy biskupami Bertramnem a Palladiuszem zarzucającymi sobie nawzajem krzywoprzysięstwa, cudzołóstwo i nierząd, Grzegorz przytoczył słowa pozostałych biskupów, którzy ubolewali, że chwast diabelski tak bujnie rozrósł się wśród biskupów Pańskich ${ }^{67}$. Wiele miejsca poświęcił Grzegorz niepokojom, które dotknęły żeński klasztor w Poitiers założony przez

62 Por. Gregorius Turonensis, Historiarum libri VII 35, s. 356, Historie, s. 218.

63 Na temat Eberulfa, zob. Eberulfus, w: The Prosopography of Later Roman Empire A. D. 527-641, t. 3A, red. A.J.R. Martindale, Cambridge 1992, s. 432.

64 Por. Gregorius Turonensis, Historiarum libri VII 22, s. 341, Historie, s. 345.

65 Por. Gregorius Turonensis, Historiarum libri VII 22, s. 342, Historie, s. 346.

66 Por. Gregorius Turonensis, Historiarum libri VIII 34, s. 403, Historie, s. 397. Problem alkoholu w społeczeństwie galijskim omawia: M. Chudzikowska-Wołoszyn, Pijaństwo frankońskich elit w świetle wybranych źródet z VI-IX w., w: Oblicza alkoholu w kulturze elit od średniowiecza do współczesności, red. R. Bubczyk - B. Hołub J. Sołtys, Lublin 2015, s. 13-28.

${ }^{67}$ Por. Gregorius Turonensis, Historiarum libri VIII 7, s. 376, Historie, s. 374. 
św. Radegundę ${ }^{68}$. Mniszka Chrodechilda, zwiedziona przez diabła, zaczęła rozgłaszać, że pochodzi z królewskiego rodu i wypowiedziała posłuszeństwo opatce. Pociągnęła ona za sobą inne mniszki, wprowadzając zamęt w życie wspólnoty ${ }^{69}$. Kobiety za diabelskim poduszczeniem opuściły klasztor i nie chciały słuchać rad biskupów pragnących doprowadzić je do poprawy ${ }^{70}$.

\section{Bóg wobec bytów demonicznych}

Spektakularne w swoich przejawach działania diabła nie przesłaniały jednak Grzegorzowi wszechmocy Bożej. Wielokrotnie w swoim dziele biskup Tours wskazywał na potęgę Boga i opiekę, którą darzył On wierzących. W rozmowie z pewnym Żydem, którego bezskutecznie usiłował nawrócić, Grzegorz wyjaśniał motywy wcielenia Syna Bożego. Według biskupa człowieka opętanego przez grzech i poddanego służbie diabła Syn Boży nie mógłby odkupić, gdyby nie przyjął postaci człowie$\mathrm{ka}^{71}$. W innej dyspucie z kapłanem, który wątpił w zmartwychwstanie, Grzegorz tłumaczył, że Syn Boży przeniknął do piekieł (inferna penetrare) aby nie pozwolić człowiekowi zginąć w wiecznej śmierci ${ }^{72}$. Moc Boża przejawiała się konkretnie w uzdrowieniach opętanych przez demony oraz $\mathrm{w}$ konfrontacji z bożkami pogańskimi ${ }^{73}$. Opisując historię pustelnika Hospicjusza, biskup Tours wspominał, że mąż ten wielu ludzi

68 Na temat Radegundy, zob. J.A. Świdziński, Święci Władcy. Leksykon, Kraków 2010, s. 65-70. Szczegółowo przebieg sporu w Poitiers omawia: E.T. Dailey, Queens, Consorts, Concubines, Leiden - Boston 2015, s. 64-79.

69 Por. Gregorius Turonensis, Historiarum libri IX 39, s. 460, Historie, s. 443.

70 Por. Gregorius Turonensis, Historiarum libri IX 41, s. 468, Historie, s. 450.

71 Por. Gregorius Turonensis, Historiarum libri VI 5, s. 269-270, Historie, s. 287-288.

72 Por. Gregorius Turonensis, Historiarum libri X 13, s. 496-497, Historie, s. 475.

73 Na temat stosunku Grzegorza do kultów pogańskich, zob. Y. Hen, Paganism and Superstitions in the time of Gregory of Tours: Une question mal posée!, w: The World of Gregory of Tours, red. K.A. Mitchell - I.N. Wood, Leiden 2002, s. 229-240. 
uwolnił od złych duchów, kładąc na nich ręce. Szczegółowo zaś zrelacjonował historię uzdrowienia człowieka, który był głuchy i niemy. Święty mąż wziął poświęcony olej, wlał go choremu do ust i na czubek głowy, wypowiadając przy tym słowa „W imię Pana mojego Jezusa Chrystusa niech się otworzą uszy twoje i niech rozewrze twoje usta owa moc, która niegdyś złego czarta wypędziła z człowieka głuchego i niemego"74. Podobnie spektakularne zdarzenie objawiające wyższość Boga nad nieczystymi siłami dokonało się za sprawą diakona Wulfilaicha. Opowiadał on Grzegorzowi, jak w okolicach Trewiru z pomocą boską obalił posąg bogini Diany czczonej przez lud jako bóstwo. Kiedy już udało mu się nawrócić okoliczną ludność, tłumacząc jej, że niczym są bożki wobec Boga, postanowił usunąc posąg bogini. Mimo wysiłku wielu ludzi nie byli w stanie obalić monumentu. Diakon wspominał, że dopiero gdy w modlitwie zwrócił się do Boga, posąg udało się usunąć. Wulfilaich dopowiedział, że kiedy zniszczył posąg, całe jego ciało pokryło się złośliwymi bąblami, dopiero gdy namaścił się olejem wziętym z kościoła św. Marcina, jego ciało stało się czyste. Zdarzenie to Boży mąż przypisał działaniu nienawiści złośliwego nieprzyjaciela, będąc zapewne przekonanym, że manifestacyjnie obalając posąg, zadarł z demonicznymi mocami. Choć wypowiedziane w innym kontekście, to jednak słowa „Nie zabrakło wszakże zemsty Bożej, która zwykła bronić swoje sługi przed paszczą wściekłych psów" dobrze oddają przekonanie Grzegorza o potędze Bożej zdolnej ochronić wierzących w Niego przed czyhającymi niebezpieczeństwami ${ }^{75}$.

J. LeGoff zauważył, że czas wczesnego średniowiecza był okresem, kiedy dopiero zaczynały kształtować się wyobrażenia związane z diabłem i rolą, jaką odgrywał on w życiu ludzi. Według tego badacza dopiero rozkwit społeczeństwa feudalnego przyniósł ostateczne wyklarowanie się tego obrazu. Zdaniem francuskiego historyka „Diabeł i Pan Bóg - oto

\footnotetext{
74 Por. Gregorius Turonensis, Historiarum libri VI 6, s. 273-275, Historie, s. 291.

75 Por. Gregorius Turonensis, Historiarum libri VIII 12, s. 378, Historie, s. 376.
} 
para dominująca nad życiem średniowiecznego chrześcijaństwa, a walka między nimi dwoma jest dla ludzi wieków średnich wytłumaczeniem każdego zdarzenia i zjawiska" "76. W Historiach Grzegorza z Tours diabeł $\mathrm{i}$ inne byty demoniczne pojawiają się pod różnymi nazwami. W historycznym dziele biskupa opisane zostało wiele sposobów oddziaływania złych duchów zarówno na jednostki, jak i społeczności (przypadek wspólnoty klasztornej w Poitiers). W inspiracji diabelskiej Grzegorz widział przyczynę prześladowania chrześcijan, występowania herezji, magii, wróżbiarstwa. Kilkukrotnie w dziele uczonego biskupa pojawił się motyw kobiety będącej narzędziem diabła. Zły duch według pasterza z Tours był inspiratorem grzechów, zarówno pierworodnego, jak i innych (pijaństwo, rozboje). Grzegorz szczególnie podkreślał „pomoc” diabła w dokonaniu samobójstwa. Jednak działania diabła, nawet te najbardziej spektakularne, nie przysłaniały biskupowi Tours wszechmocy Bożej. W kilkukrotnie powtarzanym na kartach dzieła wyznaniu wiary Grzegorz dawał wyraz swemu przekonaniu o historycznym zwycięstwie Chrystusa nad diabłem i jego aktualizacji w cudach dokonywanych przez świętych mężów.

\section{„Himself, full of spite, does all he can to harm those who seek God". The Impact of Demonic Beings on the Fate of Individuals and Communities in Gregory of Tours' Histories}

(summary)

Gregory of Tours' Histories are one of the most important sources for the shift period between antiquity and middle ages. Their attention is focused on gallic society. The main characters are kings of the Merovingian dynasty, landlords and bishops. Apart from secular protagonists Gregory pays some attention to spiritual beings. He is convinced about God's providence and Christ's role in humans redemption. The bishop of Tours gives also some information about evil beings: the Devil and demons. Gregory uses many names to describe demonic reality: the Devil, Satan, prince of darkness, demon or demons. Even though he doesn't describe it in detail he makes an impression that he is aware of some internal hierarchy between demonical beings. Gregory says much about actions taken by the Devil in the society of Gaul. He describes demonic possessions, acts of violence conducted under the inspiration of evil spirit as well as disorder caused by him in the community

76 J. Le Goff, Kultura średniowiecznej Europy, Warszawa 1970, s. 164. 
of Poitiers. Although the evil is strong and makes a lot of noise, it's still subordinated to Lord. Gregory confess his firmly belief that the story of the world lies in the hands of God.

Keywords: Gregory of Tours; Histories; Gaul; miracles; Devil; Satan; demons

\title{
„Zazdrośnik ten bezustannie usiłuje szkodzić tym, którzy szukają Boga”. Wpływ bytów demonicznych na losy jednostek i społeczności w Historiach Grzegorza z Tours
}

\author{
(streszczenie)
}

Historie Grzegorza z Tours są ważnym źródłem do poznania dziejów Galii przełomu starożytności i średniowiecza. Są również istotnym świadectwem umożliwiającym badania mentalności ludzi tamtego czasu. Bohaterowie opisywani przez biskupa Tours byli przekonani o wpływie bytów duchowych na losy człowieka i społeczności. Obok wiary w Boga byli świadomi istnienia i działania bytów demonicznych. Dla ich nazwania Grzegorz używał różnych terminów, m.in. diabeł, szatan, książę ciemności, demon. Podawał też przykłady ich zgubnego wpływu na ludzi i społeczność, opisując przypadki opętania, samobójstwa, przemocy, zamętu. Jednak, pomimo opisywania gwałtownych i spektakularnych działań zła, Grzegorz był przekonany, że to Bóg odgrywa wiodącą rolę w historii zbawienia.

Słowa kluczowe: Grzegorz z Tours; Historie; Galia; cuda; diabeł; Szatan; demony

\section{Bibliografia}

\section{Źródla}

Athanasius, Vita Antonii, Athanase d'Alexandrie, Vie d'Antoine, Introduction, Texte Critique, Tradution, Notes, et Index, ed. G.J.M. Basterlink, Sources Chretiennes 400, Paris 1994, tł. Z. Brzostowska, Św. Atanazy Aleksandryjski, Żywot świętego Antoniego Pustelnika, w: Antoni Pustelnik, Pisma, Warszawa 1987, s. 55-111.

Gregorius Turonensis, Historiarum libri X, ed. B. Krusch, Monumenta Germaniae Historica, Scriptores Rerum Merovingicarum I/1, Hannover 1937-1951, tł. K. Liman - T. Richter, Grzegorz z Tours, Historie. Historia Franków, Kraków 2012.

Liber Pontificalis XCVII - CXII (ann. 772-891), Synodi et Collectiones Legum 10, tł. Księga Pontyfików 97-112 (772-891), ŹMT 75, Kraków 2015. 


\section{Opracowania}

Breukelaar A.H.B., Historiography and Episcopal Authority in Sixth-Century Gaul. The Histories of Gregory of Tours interpreted in their historical context, Göttingen 1994.

Choda K.C., Facing a Second Death: Narrating and Silencing Hell in the Works of Gregory of Tours, „Graeco-Latina Brunensia” 22/2 (2017) s. 201-216.

Chudzikowska-Wołoszyn M., Pijaństwo frankońskich elit w świetle wybranych źródet z VI-IX w., w: Oblicza alkoholu w kulturze elit od średniowiecza do współczesności, red. R. Bubczyk - B. Hołub, J. Sołtys, Lublin 2015, s. 13-28.

Dailey E.T., Queens, Consorts, Concubines. Gregory of Tours and Women of the Merovingian Elite, Leiden - Boston 2015.

Danielou J. - Marrou H.I., Historia Kościoła, t. 1, Warszawa 1986.

Fossum J., Simon Magus, w: Dictionary of Deities and Demons in the Bible, red. K. van der Toom - B. Becking - P.W. van der Horst, Leiden - Boston - Köln 1999, s. $779-781$.

Le Goff J., Kultura średniowiecznej Europy, Warszawa 1970.

Heinzelmann M., Gregory of Tours: The Elements of a Biography, w: A Companion to Gregory of Tours, red. A.C. Murray, Leiden - Boston 2015, s. 7-34.

Hen Y., Paganism and Superstitions in the time of Gregory of Tours: Une question mal posée! w: The World of Gregory of Tours, red. K.A. Mitchell - I.N. Wood, Leiden 2002, s. 229-240.

Kobielus S., Bestiarium chrześcijańskie. Zwierzęta w symbolice i interpretacji. Starożytność i średniowiecze, Warszawa 2002.

Mathisen R.W., Ecclesiastical Factionalism and Religious Controversy in Fifth-Century Gaul, Washington 1989.

Nie G. de, Views from a Many-Windowed Tower. Studies of imagination in the works of Gregory of Tours, Amsterdam 1987.

Oberman H.M., Marcin Luter. Człowiek między Bogiem a diabłem, Gdańsk 2004.

Paczkowski M.C., Wczesnochrześcijańska symbolika o charakterze ponerologicznym. Wybrane przykłady, VoxP 59 (2013) s. 39-65.

Russell J.B., Satan. The early christian tradition, Ithaca - London 1981. 
Studer B., Demon, w: Encyclopedia of Ancient Christianity. Produced by the Institutum Patristicum Augustinianum, t. 1, red. A di Berardino, Westmontt 2014, s. 688-692.

Szram M., Ciało zmartwychwstałe w myśli patrystycznej przełomu II i III wieku, Lublin 2010 .

Szram M., Geneza herezji wczesnochrześcijańskich w ujęciu Filastriusza z Brescii, VoxP 65 (2016) s. 631-651.

Świdziński J.A., Święci Władcy. Leksykon, Kraków 2010.

The Prosopography of Later Roman Empire A. D. 527-641, t. 3A, red. J.R. Martindale, Cambridge 1992.

The Prosopography of Later Roman Empire A. D. 527-641, t. 3B, red. J.R. Martindale, Cambridge 1992.

Vos N., Demons and the Devil in Ancient and Medieval Christianity: Introduction, Summary, Reflection, w: Demons and the Devil in ancient and medieval Christianity, red. N. Vos - W. Otten, Leiden - Boston 2011, s. 3-36.

Wesołowski P., Geneza i istota postaci Antychrysta we wczesnochrześcijańskiej literaturze tacińskiej, „Seminare. Poszukiwania naukowe” 20 (2004) s. 423-439.

Wiśniewski R., Szatan i jego słudzy. Rola diabła i demonów w łacińskiej literaturze hagiograficznej IV-V wieku, Kraków 2003.

Wiśniewski R., Wieszczacy opętani i ich klienci w późnej starożytności, red. E. Wipszycka - T. Derda, Chrześcijaństwo u schyłku starożytności. Studia Źródłoznawcze 5, Kraków 2004, s. 345-370.

Zając R., Przewodnik po niebie, piekle i ich mieszkańcach, Kraków 2014. 